\title{
Kajian Kondisi dan Nilai Ekonomi Manfaat Ekosistem Terumbu Karang di Pantai Wediombo, Kabupaten Gunung Kidul, Daerah Istimewa Yogyakarta
}

\author{
Heriawan Maulana', Sutrisno Anggoro ${ }^{1,2}$, Bambang Yulianto ${ }^{1,3}$ \\ ${ }^{1}$ Magister Ilmu Lingkungan, Program Pasca Sarjana Universitas Diponegoro, Semarang, Indonesia; email: onee awan@yahoo.com \\ 2Program Magister dan Doktor Manajemen Sumber Daya Perairan, Program Pascasarjana Universitas Diponegoro \\ ${ }^{3}$ Fakultas Perikanan dan Ilmu Kelautan, Universitas Diponegoro
}

\begin{abstract}
ABSTRAK
Perairan Wediombo Kabupaten Gunung Kidul yang telah ditetapkan sebagai Pencadangan Kawasan Konservasi Perairan Daerah pada tahun 2013. Pemanfaatan wilayah Pantai Wediombo oleh masyarakat sebagai lokasi pendaratan ikan dan pariwisata mengakibatkan peningkatan tekanan terhadap ekosistem perairan khususnya terumbu karang. Sebagai common property, kerusakan ekosistem terumbu karang tidak dirasakan sebagai kerugian ekonomi sehingga eksploitasi dari manfaat ekosistem terumbu karang menjadi tidak terkendali. Pengelolaan Pantai Wediombo menjadi tantangan bagi stakeholder untuk dapat mengoptimalkan pemanfaatan jasa lingkungan bagi kesejahteraan masyarakat. Salah satu komponen upaya pengelolaannya yaitu dengan melakukan pemantauan kondisi terumbu karang di Pantai Wediombo. Valuasi ekonomi ekosistem termbu karang merupakan instrumen untuk menilai produk dan jasa yang dihasilkan oleh ekosistem terumbu karang. Tujuan dari penelitian ini adalah untuk mengetahui kondisi ekosistem terumbu karang yang diwakili oleh persen tutupan terumbu karang dan nilai manfaat ekosistem terumbu karang yang diwakili oleh produk perikanan yang dihasilkan dari ekosistem terumbu karang di Pantai Wediombo. Metode yang digunakan adalah metode survei. Metode pengumpulan data kondisi terumbu karang mengacu pada metode Line Intercept Transect (LIT). sedangkan nilai ekonomi manfaat ekosistem terumbu karang dihitung menggunakan metode Effect on Productivity. Pada penelitian diperoleh hasil prosentase tutupan terumbu karang di Pantai Wediombo sebesar 25,29\% dengan status kondisi rusak sedang. nilai ekonomi aktual ekosistem terumbu karang di Pantai Wediombo sebesar Rp. 634.553.504,-, sedangkan nilai manfaat sekarang dari ekosistem terumbu karang di Pantai Wediombo sebesar Rp. 20.304.872,-.
\end{abstract}

Kata kunci: Ekosistem Terumbu Karang, Valuasi Ekonomi, Pantai Wediombo

\begin{abstract}
Bodies Wediombo Gunung Kidul regency which has been designated as a Local Backup Water Conservation Area in 2013. Utilization Wediombo Turkish territory by the public as a fish landing site and tourism resulted in increased pressure on aquatic ecosystems, especially coral reefs. As common property, damage to coral reefs is not perceived as economic losses so that the exploitation of the benefits of coral reef ecosystems had become unmanageable. Wediombo Coastal management is a challenge for stakeholders to be able to optimize the use of environmental services for the welfare of society. One component management efforts is by monitoring the condition of coral reefs in Wediombo Beach. Economic valuation of coral ecosystems termbu is an instrument to assess the products and services produced by a coral reef ecosystems. The purpose of this study was to determine the condition of coral reef ecosystems are represented by percent cover of coral reefs and coral reef ecosystems benefit value represented by the fishery products produced from coral reef ecosystems Wediombo Beach. The method used is a survey method. Methods of data collection coral reef condition refers to a method Line Intercept Transect (LIT). while the economic value of coral reef ecosystem benefits are calculated using methods Effect on Productivity. In the research results the percentage of coral reef cover in Turkish Wediombo of $25.29 \%$ with a damaged condition status. the true economic value of coral reef ecosystems Wediombo Coast of Rp. 634553 504, -, while the value of current benefits of coral reef ecosystems Wediombo Coast of Rp. 20,304,872, -.
\end{abstract}

Keywords: Coral Reef Ecosystems, Economic Valuation, Turkish Wediombo

Cara sitasi: Maulana, H., Anggoro, S., Yulianto, B. (2016). Kajian Kondisi dan Nilai Ekonomi Manfaat Ekosistem Terumbu Karang di Pantai Wediombo, Kabupaten Gunung Kidul, Daerah Istimewa Yogyakarta. Jurnal Ilmu Lingkungan,14(2),82-87, doi:10.14710/jil.14.2.82-87

\section{PENDAHULUAN}

Pantai Wediombo merupakan bagian dari kawasan perairan yang telah ditetapkan sebagai Cadangan Kawasan Konservasi Perairan Daerah jenis
Suaka Alam Perairan dengan Keputusan Bupati Gunungkidul Nomor: 271/KPTS/2013 tanggal 2 September 2013 tentang Pencadangan Kawasan Konservasi Perairan. Pencadangan kawasan perairan 
Wediombo dan sekitarnya meliputi 192,79 Ha kawasan daratan dan 3.195,67 Ha kawasan perairan degan total kawasan seluas 3.388,40 Ha (Dinas Kelautan dan Perikanan DIY, 2014). Pemanfaatan wilayah Pantai Wediombo oleh masyarakat sebagai lokasi pendaratan ikan dan pariwisata mengakibatkan peningkatan tekanan terhadap ekosistem perairan khususnya terumbu karang. Sebagai common property, kerusakan ekosistem terumbu karang tidak dirasakan sebagai kerugian ekonomi sehingga eksploitasi dari manfaat ekosistem terumbu karang menjadi tidak terkendali. Pengelolaan Pantai Wediombo menjadi tantangan bagi para stakeholder untuk dapat mengoptimalkan pemanfaatan jasa lingkungan bagi kesejahteraan masyarakat. Salah satu komponen upaya pengelolaannya yaitu dengan melakukan pemantauan kondisi terumbu karang di Pantai Wediombo. Valuasi ekonomi ekosistem termbu karang merupakan instrument untuk menilai produk dan jasa yang dihasilkan oleh ekosistem terumbu karang. Dengan instrumen tersebut diharapkan dapat meningkatkan penghargaan dan kesadaran masyarakat akan pentingnya jasa yang dihasilkan oleh sumberdaya alam dan lingkungan (Rachmansyah \& Maryono, 2004). Tujuan dari penelitian ini adalah untuk mengetahui kondisi ekosistem terumbu karang yang diwakili oleh persen tutupan terumbu karang dan nilai manfaat ekosistem terumbu karang yang diwakili oleh produk perikanan yang dihasilkan dari ekosistem terumbu karang di Pantai Wediombo.

Ekosistem terumbu karang merupakan ekosistem yang paling kaya dan produktif di muka bumi (Burke, Reytar, Spalding, \& Perry, 2012). Terumbu karang mampu memberikan manfaat bagi masyarakat pesisir untuk mencukupi kebutuhan hidupnya. Selain sumber pangan, terumbu karang juga merupakan sumber pendapatan bagi masyarakat pesisir. Bagi berbagai spesies ikan, terumbu karang merupakan tempat asuhan, tempat memijah dan tempat mencari makan. Bagi para pelancong, terumbu karang merupakan daya tarik wisata yang mengundang kekaguman karena keindahannya. Keberadaan terumbu karang juga berperan dalam melindungi wilayah pesisir dari terpaan badai. Akan tetapi terumbu karang juga merupakan ekosistem yang rentan terhadap kerusakan. Ketergantungan yang tinggi akan sumber daya laut mengakibatkan pemanfaatan yang berlebihan dan perusakan terumbu karang (Burke, Selig, \& Spalding, 2002).

Terumbu karang merupakan asosiasi di lautan yang terbentuk seluruhnya oleh kegiatan biologis. Terumbu adalah endapan-endapan masif yang penting dari kalisum karbonat yang terutama dihasilkan oleh karang dengan sedikit tambahan dari alga berkapur dan organisme-organisme lain yang menghasilkan kalsium karbonat (Nybakken, 1992). Manfaat langsung yang diberikan oleh terumbu karang yaitu habitat organisme lainnya dalam mencari makan (feeding ground), tempat asuhan dan pembesaran (nursery ground), dan tempat pemijahan (spawning ground), pariwisata bahari, dan lain-lain. Sedangkan manfaat tak langsung yang diberikan oleh terumbu karang yaitu peran sebagi pelindung pantai dari terpaan gelombang dan penahan abrasi (Aldilla, 2014).

Nilai ekonomis dari terumbu karang yang menonjol adalah sebagai lokasi penangkapan berbagai jenis biota laut baik konsumsi maupun hias, bahan bangunan, bahan baku farmasi dan sebagai tempat rekreasi. Sebagai sebuah ekosistem, terumbu karang tidak memiliki nilai pasar (non market base) (Matulis, 2014). Salah satu nilai yang dapat mewakili nilai ekonomi terumbu karang adalah nilai produktifitas perikanan. Fungsi terumbu karang sebagai feeding ground, spawning ground dan nursery ground dapat disetimasi dengan nilai output dari ikan karang (Romadhon, 2014).

\section{METODE PENELITIAN}

\subsection{Waktu dan Lokasi Penelitian}

Penelitian ini dilaksanakan pada bulan September hingga Nopember 2015 di Pantai Wediombo, Desa Balong, Kecamatan Girisubo, Kabupaten Gunungkidul, Daerah Istimewa Yogyakarta.

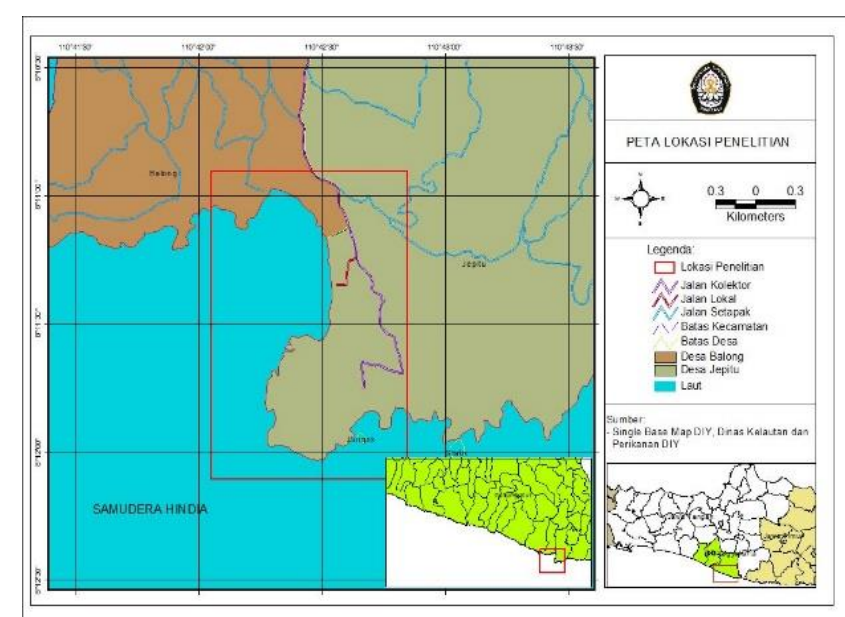

Gambar 1. Peta Lokasi Penelitian

\subsection{Metode}

Metode yang digunakan adalah metode survei. Metode pengumpulan data kondisi terumbu karang mengacu pada metode Line Intercept Transect (LIT)(Johan, 2003) di 3 (tiga) titik stasiun. Panjang garis transek $20 \mathrm{~m}$ dibentangkan pada ekosistem terumbu karang kemudian bentuk pertumbuhan karang (life form) dicatat pada datasheet. Selanjutnya dilakukan pengolahan data dengan cara penghitungan Persentase Penutupan (percent cover) menurut persamaan English et al (1995) dalam (Tuwo, 2011), yaitu:

$$
P_{t}=\frac{P_{j c}}{P_{j t}} \times 100 \%
$$


Keterangan:

$\mathrm{P}_{\mathrm{t}} \quad=$ Prosentase tutupan karang

$\mathrm{P}_{\mathrm{jc}} \quad=$ Total panjang kategori atau genus

$\mathrm{P}_{\mathrm{jt}} \quad$ = Panjang transek

Sebagai penduga kondisi ekosistem terumbu karang, data prosentase tutupan karang dikategorikan berdasarkan Keputusan Menteri Lingkungan Hidup Nomor 4 tahun 2001 tentang Kriteria Baku Kerusakan Terumbu Karang (Yusuf, 2013), sebagai berikut:

Tabel 1. Tabel Kriteria Baku Kerusakan Terumbu Karang Prosentase Luasan Terumbu $\%$

Karang yang Hidup

\begin{tabular}{lcl} 
Rusak & Buruk & $0-24,9$ \\
& Sedang & $25-49,9$ \\
Baik & Baik & $50-74,9$ \\
& Baik Sekali & $75-100$ \\
\hline
\end{tabular}

Fungsi terumbu karang sebagai feeding ground, spawning ground dan nurshery ground dapat disetimasi dengan nilai output dari ikan karang (Romadhon, 2014). Peritungan nilai ekonomi manfaat terumbu karang digunakan data sekunder hasil produksi nelayan Pantai Wediombo yang diperoleh dari Dinas Kelautan dan Perikanan Kabupaten Gunungkidul. Luasan terumbu karang diestimasi dari pengolahan data citra satelit tahun 2003 dan 2015. Adapun prosedur dalam analisis valuasi ekonomi terumbu karang sebagai berikut:

1. Menghitung nilai ekonomi aktual (Net Benefit Income Approach) yang didapatkan dari pendapatan bersih nelayan per tahun dikalikan dengan jumlah nelayan kemudian dibagi dengan luas terumbu karang.

2. Menghitung nilai manfaat sekarang dengan mendiskon aliran bersih dari manfaat terumbu karang yang diambil sebagai indikator nilai sekarang (present value) kemudian membagi dengan total present value produksu terumbu karang dengan luasan terumbu karang, maka diperoleh nilai per hektar terumbu karang.

Present Value Generated per Hectare Model-Income Approach

$$
P V \text { per Hectare }=\left[\sum_{t=0}^{T} \frac{B_{t}}{(1+r)^{t}}\right] / L
$$

Keterangan:

$$
\begin{aligned}
& \mathrm{B}_{\mathrm{t}} \quad=\text { manfaat produksi perikanan dari } \\
& \text { ekosistem terumbu karang } \\
& =\text { jumlah tahun proyeksi nilai } \\
& \text { = real discount rate } \\
& \text { = luas kawasan terumbu karang }
\end{aligned}
$$

3. Menghitung nilai manfaat ekonomi sekarang memasukkan faktor residual rent yang merupakan perbedaan antara biaya faktor produksi dan nilai ekstraksi dari sumberdaya. Residual rent dapat dilihat sebagai kontribusi sistem alam atau pendapatan bersih terhadap nilai ekonomi total.

Present Value Residual Rent per Hectare ModelIncome Approach

PV Residual Rent per Hectare Model

$$
=\left[\sum_{t=0}^{T} \frac{B_{t}-C_{t}}{(1+r)^{t}}\right] / L
$$

Keterangan:

$$
\begin{array}{ll}
\mathrm{B}_{\mathrm{t}} & =\text { manfaat produksi perikanan dari } \\
& \text { ekosistem terumbu karang } \\
\mathrm{Ct} & =\text { biaya produksi perikanan } \\
\mathrm{t} & =\text { jumlah tahun proyeksi nilai } \\
\mathrm{r} & =\text { real discount rate } \\
\mathrm{L} & =\text { luas kawasan terumbu karang }
\end{array}
$$

\section{HASIL DAN PEMBAHASAN}

Tipe terumbu karang di Pantai Wediombo merupakan terumbu karang tepi (fringing reef). Keberadaan terumbu karang tepi (fringing reef) ditandai dengan adanya karang yang tumbuh mulai dari tepian pantai dan tidah dipisahkan dengan adanya gobah besar yang membentuk paparan terumbu (reef flat). Tipe terumbu karang ini ditemukan hampir diseluruh pantai tropis dimana pertumbuhan terumbu karang menuu permukaan laut ke arah laut lepas dan berfungsi sebagai pelindung daratan dari gempuran ombak.

Hasil pengamatan pada tiga stasiun menunjukkan bahwa kondisi terumbu karang di perairan Pantai Wediombo adalah kategori buruk hingga sedang, di kedalaman pengamatan $6 \mathrm{~m}$ sampai dengan $19 \mathrm{~m}$. Berikut adalah bentuk pertumbuhan life form karang di perairan Pantai Wediombo tersaji pada Tabel 2.

Tabel 2. Bentuk Perumbuhan (life form) Karang di Pantai Wediombo

\begin{tabular}{lllll}
\hline $\begin{array}{l}\text { Kategori life } \\
\text { form }\end{array}$ & $\begin{array}{l}\text { Stasiun I } \\
(\%)\end{array}$ & $\begin{array}{l}\text { Stasiun } \\
(\%)\end{array}$ & $\begin{array}{l}\text { Stasiun } \\
\text { III (\%) }\end{array}$ & $\begin{array}{l}\text { Life } \\
\text { karang (\%) }\end{array}$ \\
\hline Acropora & 0 & 4,7 & 2,45 & 2,38 \\
Non Acropora & 0 & 34,15 & 35,1 & 23,08 \\
Dead & 12,05 & 59,15 & 61,7 & 44,3 \\
Scleractinia & & & & \\
Algae & 0,25 & 1,25 & 0,77 & 0,76 \\
Other Fauna & 0 & 0,75 & 0 & 0,25 \\
Abiotic & 87,7 & 0 & 0 & 29,23 \\
\hline
\end{tabular}

Persen tutupan karang di perairan Pantai Wediombo yang masuk dalam kondisi sedang terletak di sebelah ujung selatan sebesar 37,55\% dan di bagian tengah teluk Wediombo yaitu sebesar 38,85\%. Lokasi pengamatan yang terletak di sebelah utara teluk Wediombo menunjukan tutupan karang kategori buruk dengan persentase sebesar 0\%. Persen tutupan karang di Pantai Wediombo disajikan pada Tabel 3. 
Maulana, H., Anggoro, S., dan Yulianto, B. (2016). Kajian Kondisi dan Nilai Ekonomi Manfaat Ekosistem Terumbu Karang di Pantai Wediombo, Kabupaten Gunung Kidul, Daerah Istimewa Yogyakarta. Jurnal IImu Lingkungan,14(2),82-87, doi:10.14710/jil.14.2.82-87

Tabel 3. Persen Tutupan Karang di Pantai Wediombo

\begin{tabular}{lll}
\hline Stasiun & Rata-rata (\%) & Kategori \\
\hline Stasiun I & 0 & Buruk \\
Stasiun II & 38,22 & Sedang \\
Stasiun III & 37,65 & Sedang \\
Jumlah & 25,29 & Sedang \\
\hline
\end{tabular}

Kondisi terumbu karang pada stasiun I berdasarkan analisis yang dilakukan termasuk dalam kategori buruk dengan nilai persentase $0 \%$. Persentase penyusun ekosistem terumbu karang di stasiun I didominasi oleh pasir (S) sebesar 87\%, kemudian disusul dead coral with alga covering (DCA) sebesar $12,05 \%$ dan algae assemblage (AA) sebesar $0,25 \%$. Hasil pengamatan pada stasiun I tersebut dimungkinkan karena kedalaman lokasi penyelaman mencapai $19 \mathrm{~m}$ dengan kondisi arus kuat $0,2 \mathrm{~m} /$ detik sehingga substrat dasar mudah terangkat dan mempengaruhi masuknya intensitas matahari. Aktifitas penangkapan ikan yaitu keluar masuknya kapal nelayan di tempat pendaratan ikan sekitar stasiun I, diduga berperan dalam teraduknya substrat dasar sehingga menurunkan tingkat kecerahan perairan. Kecerahan merupakan gambaran kemampuan cahaya matahari dalam menembus lapisan perairan pada kedalaman tertentu. Kecerahan sangat berpengaruh dalam produktifitas primer perairan khususnya organisme fotosintesis seperti fitoplankton dan tumbuhan air lainnya (Aldilla, 2014). Pada ekosistem terumbu karang, intensitas cahaya matahari sangat dibutuhkan oleh alga karang (zooxanthelae) dalam proses fotosintesis. Hasil dari proses fotosintesis tersebut dimanfaatkan oleh hewan karang untuk proses kalsifikasi dan respirasi. Tanpa cahaya yang cukup, laju fotosintesis akan terganggu sehingga akan menurunkan kemampuan karang untuk membentuk terumbu. Oleh karena itu distribusi vertikal terumbu karang dibatasi oleh efektifitas cahaya matahari yang masuk ke dalam perairan (Hatcher, 1997; Nybakken, 1992; Racault et al., 2015; Smith, 1978).

Kondisi terumbu karang pada stasiun II dan III menunjukkan persen tutupan karang kategori sedang yaitu 38,22\% dan 37,65\%. Dapat ditarik rata-rata persen tutupan karang yang dapat menggambarkan kondisi terumbu karang di Pantai Wediombo termasuk dalam kategori sedang dengan persen tutupan sebesar 25,29\%. Pada stasiun II komposisi penyusun life form dasar perairan yaitu Acropora branching (ACB) 0,7\%, Acropora tabulate (ACT) 2,65\%, Acropora submassive (ACS) 1,35\%, Coral massive (CB) 33,25\% dan Coral encrusting (CE) 0,9\%. Sedangkan pada stasiun III komposisi penyusun life form dasar perairan yaitu Acropora encrusting (ACE) $2,45 \%$, Coral massive (CB) 18,2\%, Coral encrusting (CE) 16,4\% dan Coral submassive (CS) 0,5\%. Berdasarkan komposisi penyusun ekosistem terumbu karang pada stasiun II dan III menunjukkan pertumbuhan karang didominasi oleh bentuk Coral massive dan Coral encrusting. Keberadaan bentuk tumbuh karang Coral massive (CM) dan Coral encrusting (CE) yang dominan diduga sebagai bentuk adaptasi terumbu karang terhadap lingkungannya. Lingkungan Pantai Wediombo yang berhadapan langsung dengan Samudera Hindia memiliki karakteristik gelombang dan arus laut yang kuat. Hal ini mengakibatkan karang keras dari kelompok Akropora tidak akan tahan terhadap hempasan gelombang dan arus Samudera Hindia (Dinas Perikanan dan Kelautan DIY, 2001; Ramachandran et al., 2005).

Jumlah nelayan menurut data Dinas Kelautan dan Perikanan Kabupaten DIY sampai dengan bulan Juni 2015 adalah 39 orang. Nelayan di Pantai Wediombo rata-rata menangkap ikan karang menggunakan pancing ulur (hand line) dan jaring insang (gill net). Sarana penangkapan ikan yang digunakan yaitu perahu jukung dengan mesin tempel. Ada pula nelayan yang menangkap ikan dengan cara memancing di lokasi perbukitan kapur di sekitar teluk Wediombo. Dalam satu trip penangkapan biasanya kapal jukung diawaki oleh dua orang nelayan. Penangkapan biasanya pada musim timur dan musim peralihan, kurang lebih 8 bulan efektif dan bersifat one day fishing. Dalam satu bulan, nelayan di Pantai Wediombo rata-rata melakukan 15-20 trip/nelayan atau 120-160 trip/tahun.

Tabel 4. Produksi dan Nilai Produksi Ikan di Pantai Wediombo tahun 2011-2014

\begin{tabular}{lccc}
\hline No & Tahun & Produksi $(k g)$ & $\begin{array}{l}\text { Nilai } \\
\text { (Rp) }\end{array}$ \\
\hline 1. & 2011 & 188.969 & 1.670 .937 .314 \\
2. & 2012 & 99.087 & 698.093 .900 \\
3. & 2013 & 76.699 & 1.029 .352 .000 \\
4. & 2014 & 19.460 & 244.310 .800 \\
\hline \multicolumn{4}{r}{} \\
\hline
\end{tabular}

Berdasarkan rata-rata produksi dan nilai produksi ikan di Pantai Wediombo pada Table 4, apabila jumlah nelayan Pantai Wediombo sebanyak 39 orang melakukan kegiatan penangkapan sebanyak 2.340 trip/tahun, maka estimasi jumlah ikan karang yang ditangkap oleh nelayan Pantai Wediombo per tahun sebesar 41,05 kg/trip dengan nilai pendapatan nelayan sebesar Rp. 389.177,-/trip.

Tabel 5. Rincian Estimasi Manfaat Bersih Nelayan di Pantai Wediombo

\begin{tabular}{cll}
\hline & Klasifikasi & $\begin{array}{l}\text { Rupiah } \\
\text { (Rp)/Tahun/Trip }\end{array}$ \\
\hline- & Penerimaan & 46.701 .205 \\
- & Biaya & 14.160 .000 \\
- & Pendapatan & 32.541 .205 \\
\hline
\end{tabular}

Berdasarkan Table 5 estimasi manfaat bersih nelayan sebesar Rp. 32.541.205,-/tahun/trip. Jika pada setiap trip terdiri dari dua orang nelayan, maka manfaat bersih yang didapatkan oleh setiap nelayan Pantai Wediombo sebesar Rp. 16.270.603,-/tahun. Dengan menggunakan estimasi pendapatan bersih 
nelayan, maka nilai ekosistem terumbu karang sebagai faktor input bagi produktifitas tangkapan yang menjadi hasil akhir bagi masyarakat dapat dihitung secara moneter.

Tabel 6. Nilai Estimasi Ekonomi Aktual Ekosistem Terumbu Karang di Pantai Wediombo

\begin{tabular}{lll}
\hline Klasifikasi & Unit & Jumlah \\
\hline Pendapatan bersih & Rupiah & 16.270 .603 \\
Jumlah nelayan & Orang & 39 \\
Luas & Hektar & 13,68 \\
Nilai Aktual & Rupiah & 634.553 .504 \\
Nilai Aktual per Hektar & Rupiah & 46.385 .490 \\
& & \\
\hline
\end{tabular}

Nilai sekarang (present value) dari manfaat terumbu karang diperoleh dengan mendiskonto aliran bersih dari manfaat terumbu karang. Selanjutnya nilai sekarang dari terumbu karang tersebut dibagi dengan luasan terumbu karang, sehingga dapat dihasilkan nilai sekarang per hektar terumbu karang. Pada penelitian ini digunakan discount rate $15 \%$ yang merupakan nilai tertinggi discount rate untuk analisis ekonomi dalam pemanfaatan sumberdaya. Bank Dunia sering mengajukan angka-angka 10\%,12\% dan 15\% sebagai social discount rate yang rasional untuk negaranegara berkembang (Indonesian National Coordinating Committee CTI-CFF, 2013). Jika proyeksi manfaat ekosistem terumbu karang lima tahun mendatang, maka nilai sekarang dari manfaat terumbu karang di Pantai Wediombo dapat diduga pada Tabel 7.

Tabel 7.Nilai Estimasi Manfaat Sekarang (Present Value Benefit) Ekosistem Terumbu Karang di Pantai Wediombo

\begin{tabular}{|c|c|c|c|}
\hline \multicolumn{2}{|c|}{ Klasifikasi } & Unit & Jumlah \\
\hline $\begin{array}{l}\text { Luas } \\
\text { Karang }\end{array}$ & Terumbu & Hektar & 13,68 \\
\hline $\begin{array}{l}\text { Present } \\
\text { Benefit }\end{array}$ & Value & Rupiah & 20.304 .872 \\
\hline $\begin{array}{l}\text { Present } \\
\text { Benefit } \\
\text { Hectare }\end{array}$ & $\begin{array}{r}\text { Value } \\
\text { per }\end{array}$ & Rupiah & 1.484 .272 \\
\hline
\end{tabular}

Tabel 7 di atas menunjukkan bahwa manfaat terumbu karang di Pantai Wediombo jika dinilai dengan nilai sekarang sebesar Rp. 20.304.872,- atau Rp. 1.484.272,- per hektar.

Untuk memperoleh nilai present value residual rent digunakan perbedaan antara biaya faktor produksi dan nilai ekstraksi sumberdaya. Residual rent dapat dilihat sebagai kontribusi sistem alam atau pendapatan bersih terhadap nilai ekonomi total.

Tabel 8. Nilai Estimasi Present Value Residual Rent dari Ekosistem Terumbu Karang di Pantai Wediombo

\begin{tabular}{lll}
\hline Klasifikasi & Unit & Jumlah \\
\hline Luas Terumbu Karang & Hektar & 13,68 \\
Present Value Residual Rent & Rupiah & 14.148 .350 \\
Present Value Residual Rent & Rupiah & 1.034 .236 \\
per Hectare & & \\
\hline
\end{tabular}

86
Berdasarkan Table 8 present value residual rent manfaat ekosistem terumbu karang di Pantai Wediombo sebesar Rp.14.148.350,-. Dengan luas terumbu karang 13,68 ha, maka present value residual rent per hectare sebesar Rp. 1.034.236,- per hektar.

\section{KESIMPULAN}

Prosentase tutupan terumbu karang di Pantai Wediombo sebesar 25,29\%. Menurut Keputusan Menteri Lingkungan Hidup Nomor 4 tahun 2001 tentang Kriteria Baku Kerusakan Terumbu Karang, kondisi terumbu karang di Pantai Wediombo masuk dalam kategori rusak sedang. Pertumbuhan karang didominasi bentuk tumbuh karang Coral massive (CM) dan Coral encrusting (CE), diduga sebagai bentuk adaptasi terumbu karang terhadap lingkungan dengan gelombang dan arus kuat. Berdasarkan pemanfaatan perikanan tangkap, maka nilai ekonomi aktual ekosistem terumbu karang di Pantai Wediombo sebesar Rp. 634.553.504,-, sedangkan nilai manfaat sekarang dari ekosistem terumbu karang di Pantai Wediombo sebesar Rp. 20.304.872,--

\section{SARAN}

Kondisi tutupan karang di Pantai Wediombo dalam status rusak sedang dengan persentase 25,29\% dan nilai ekonomi manfaat sekarang sebesar Rp. 20.304.872,-, diharapkan menjadi pertimbangan Pemerintah Daerah dan masyarakat di Pantai Wediombo untuk mengupayakan perlindungan dan pelestarian ekosistem perairan khususnya ekosistem terumbu karang dalam mendukung kesejahteraan masyarakat. Pencadangan kawasan Pantai Wediombo dan sekitarnya merupakan langkah yang tepat untuk upaya pengelolaan sumberdaya pesisir dan laut yang lebih baik.

\section{UCAPAN TERIMAKASIH}

Penulis mengucapkan terimakasih kepada Pusat Pembinaan Pendidikan dan Pelatihan Perencanaan BAPPENAS atas bantuan peneltian yang diberikan. Kepala Dinas Kelautan dan Perikanan DIY, Kepala Dinas Kelautan dan Perikanan Kabupaten Gunungkidul dan segenap masyarakat Desa Jepitu atas kelancaran pengambilan data di lapangan.

\section{DAFTAR PUSTAKA}

Aldilla, A. (2014). Analisis Kondisi Habitat Karang Di Pulau Rimaubalak, Kandangbalak, Dan Panjurit, Lampung Selatan. Institut Pertanian Bogor.

Burke, L., Reytar, K., Spalding, M., \& Perry, A. (2012). Menengok Kembali Terumbu Karang yang Terancam di Segitiga Terumbu Karang. World Resources Institute.

Burke, L., Selig, E., \& Spalding, M. (2002). Terumbu Karang Yang Terancam di Asia Tenggara. World Resources Institute.

Dinas Kelautan dan Perikanan DIY. (2014). Laporan Akhir Perencanaan Pengelolaan dan Zonasi Perairan Wediombo, Desa Balong dan Desa Jepitu, Kecamatan Girisubo, Kabupaten 
Maulana, H., Anggoro, S., dan Yulianto, B. (2016). Kajian Kondisi dan Nilai Ekonomi Manfaat Ekosistem Terumbu Karang di Pantai Wediombo, Kabupaten Gunung Kidul, Daerah Istimewa Yogyakarta. Jurnal Ilmu Lingkungan,14(2),82-87, doi:10.14710/jil.14.2.82-87

Gunungkidul, DIY. Yogyakarta: Dinas Kelautan dan Perikanan DIY.

Dinas Perikanan dan Kelautan DIY. (2001). Laporan Identifikasi ,Inventarisasi Terumbu Karang di Kabupaten Gunungkidul. Yogyakarta.

Hatcher, B. G. (1997). Coral reef ecosystems : how much greater is the whole than the sum of the parts? Coral Reefs, 77-91.

Indonesian National Coordinating Committee CTI-CFF. (2013). Coral Governance. (V. P. H. Nikijuluw, L. Adrianto, \& N. Januarini, Eds.) (1st ed.). Jakarta-Indonesia: Penerbit IPB Press.

Johan, O. (2003). Metode Survei Terumbu Karang Indonesia. In Training Course: Karakteristik Biologi Karang (pp. 1-8). Jakarta-Indonesia: PSK-Universitas Indonesia.

Matulis, B. S. (2014). The economic valuation of nature: A question of justice? Ecological Economics, 104, 155-157. doi:10.1016/j.ecolecon.2014.04.010

Nybakken, J. W. (1992). Biologi Laut Suatu Pendekatan Ekologis. (M. Eidman, Ed.). Jakarta: Gramedia Pustaka Utama.

Racault, M.-F., Raitsos, D. E., Berumen, M. L., Brewin, R. J. W., Platt, T., Sathyendranath, S., \& Hoteit, I. (2015). Phytoplankton phenology indices in coral reef ecosystems: Application to ocean-color observations in the Red Sea. Remote Sensing of Environment, 160, 222-234. doi:10.1016/j.rse.2015.01.019

Rachmansyah, Y., \& Maryono, J. (2004). Pentingnya Valuasi Ekonomi Dalam Pengelolaan Kawasan Konservasi yang Lestari. Jurnal Prestasi, 6(2), 1-17.

Ramachandran, S., Anitha, S., Balamurugan, V., Dharanirajan, K., Ezhil Vendhan, K., Divien, M. I. P., ... Udayaraj, a. (2005). Ecological impact of tsunami on Nicobar Islands (Camorta, Katchal, Nancowry and Trinkat). Current Science, 89(1), 195200.

Romadhon, A. (2014). Valuasi Ekonomi Manfaat Ekosistem Terumbu Karang di Pulau Sapudi, Sumenep, Madura. Agriekonomika, 3(2), 141-151.

Smith, S. V. (1978). Coral-reef area and the contributions of reefs to processes and resources of the world's oceans. Nature, 273(May), 225-226. doi:10.1038/273225a0

Tuwo, A. (2011). Pengelolaan Ekowisata Pesisir dan Laut: Pendekatan Ekologi, Sosial Ekonomi, Kelembagaan dan Sarana WIlayah. (A. Wijaya, Ed.) (Cetakan 1.). Surabaya: Brillian Internasional.

Yusuf, M. (2013). Kondisi Terumbu Karang Dan Potensi Ikan Di Perairan Taman Nasional Karimunjawa, Kabupaten Jepara. Bulletin Oseanografi Marina, 2(April), 54-60 